\title{
New Perspectives on Socialism II Socialism and Capitalism Reconsidered
}

\author{
Richard Schneirov \\ Indiana State University
}

The July 2003 special issue of the Journal of the Gilded Age and Progressive Era revisited the history of the Socialist Party of America during the Progressive Era. This second issue on "New Perspectives on Socialism" examines socialism largely outside the party context, thereby challenging the tendency of scholars and non-scholars alike to identify socialism with a party-based political movement. To the degree that the essays collected here examine party-based socialism, they focus on the gradualist or revisionist wing of the party, whose socializing and democratic reforms, programs, and ideas helped establish a context for the Progressive Era and thereafter, when a "social democratic" type of politics became intrinsic to the mainstream American politics.

It is commonplace when we consider socialism to think of it in relation to a party with socialism or communism in the name. Thus, when the question is asked "why no socialism in America," historians and social scientists tend to translate the term "socialism" to mean an electorally significant socialist party. Yet, it is well worth remembering that the political content of parties does not depend on the name of the party in question. As Martin J. Sklar points out, there has been no "Capitalist Party" in America, yet capitalism exists nonetheless, and socialism may be said to have the same kind of extra-party reality.

Of course, it takes only a moment's reflection to recognize that what activists and intellectuals called socialism was never one thing. It was always many things. It has been a powerful critique of the existing industrial system. It has always had ethical, utopian, and ideological dimensions. It also was a political program relating immediate reforms and day-to-day activity to a vision of long-term social change. Socialism was a broad movement overflowing the boundaries of party and disseminating characteristic beliefs, values, attitudes, and demands among a host of American movements and institutions.

It is also worth remembering that socialism evolved over time in tandem with the evolution of America's dynamic market society and 
its urbanization and industrialization, and with the corporate reorganization of American business. Socialism, therefore, developed in opposition to, but also in close conjunction with, capitalism, feeding upon the revulsion at its human and ecological destructiveness, its challenges to nineteenth century propertied individualism, its effronteries to humanitarian sensibilities, but also to its liberation of humanity from custom and tradition and its demonstration of the boundless possibilities for change. In reference to the modernizing weltanschauung that socialism shared with capitalism, Karl Marx in his famous paean to the bourgeoisie in The Communist Manifesto wrote that, "All that is solid melts into air, all that is holy is profaned, and man is at last compelled to face with sober sense, his real conditions of life, and his relations with his kind."

From the standpoint of what socialism and capitalism shared, socialism may be understood as a set of social relations, partly potential and partly actualized, developing within, through, and against capitalism at a particular stage of its development. This is not a new idea. Marx, Ferdinand Tonnies, Max Weber, Émile Durkheim, Georg Simmel, John Dewey, and other social theorists of the era, including many Americans, often spoke of the "socialization" and instrumental rationalization of everyday human behavior that had previously been determined within the limits of family and kin networks and face to face communities, that is the replacement of a gemeinschaft (community) with a gesellschaft (society). The diffusion of a favorable environment or indispensable matrix for socialism within the very dynamics of capitalism is evident also in the specialization and consequently intensified interdependence fostered by advancing market relations and by the spread of science and technology with their far flung communities of inquiry. Modern society took on the characteristics of what Émile Durkheim called the "organic division of labor," which he distinguished from the mechanical division of labor typical of more primitive cultures. Such a society came to be understood as a system in the sense that every element within it interacted in such complex, mutually supporting ways that changes could not be fully understood or accurately predicted without reference to the whole. Socialization also became apparent in the increasing tendency in a money economy for individuals voluntarily to associate, combine, and cooperate in pursuit

'Karl Marx, "The Communist Manifesto," in The Marx-Engels Reader, ed., Robert C. Tucker (2nd ed., New York, 1978): 476. 
of common but limited ends, thus creating a multiplicity of social interests and ramifying the general interest. Not coincidentally, the crystallization of these characteristics of modernity first became abundantly apparent to observers during the Progressive Era coincident with the rise of a vibrant socialist movement.

But, to Marxists and most professing socialists, socialism meant something more than socialization. It meant a new society transcending capitalism altogether, one that ended class divisions and exploitation and liberated human capacities through democratic association. The internal development of modern society in their view generated only the conditions for the overthrow of capitalism; the task itself would be accomplished through the "class struggle" guided by a socialist party. Thus, Marxists did not see socialism emerging the same way capitalism did, that is, taking shape as a viable, functioning, property-production system, residing side-by-side with and intermixed with feudalism and growing gradually to the point that it could eventually eclipse or suddenly overthrow feudal relations. Socialism, it seemed, could not rely on the working class entrenching itself within its own relations of production, but would be attained only by a single stroke, a revolution. Though such an interpretation of Marx's writings is arguable, at best, it remained at the core of the intellectual orthodoxy of the Second International to which the American Socialist Party belonged.

Yet, even as the Second International was dissolving in impotence during the First World War, eventually to be succeeded by the Moscow-based Communist International, an alternative theory and practice of a gradualist transition to socialism using the democratic state had taken shape. Before the war, gradualism or "revisionism" had become the majority outlook among trade unionists and increasingly made sense of the political practice of socialist parties. Revisionists questioned the purportedly inevitable trend toward the polarization of society into a homogenous, majority working class on the one hand and a tiny, socially-isolated capitalist class on the other. Accordingly, revisionists rejected the orthodox expectation that capitalism was susceptible to an imminent breakdown from an internally generated economic crisis to be followed by a short, swift transition to socialism. Revisionists countered the orthodox and Leninist scenario with their own theory of gradual change consisting of immediately realizable reforms sustained by a multi-class democratic movement. "The movement means everything for me," wrote the leading German 
revisionist, Eduard Bernstein, "and what is 'usually' called the final aim of socialism is nothing."

By the 1920s, Social Democracy became the term for socialists who were abandoning a politics of ultimate aims and taking responsibility not only for the democratic and socializing reforms they had long promoted, but for the mixed economy that in some countries they now had a hand in governing. It also became the term for the Western democratic socialist alternative to the ideology and practice of Communist parties and the Soviet Union. An American version of Social Democracy had its origin in reforms of the Theodore Roosevelt, William $\mathrm{H}$. Taft, and Woodrow Wilson administrations, came into its own during the New Deal, and developed further in the reforms of the 1960 s and thereafter.

What was variously called gradualism, revisionism, or Social Democracy, relied on selective state ownership and regulation and on democratic movements to constitute a non-revolutionary transition to socialism. The essays in this volume further explore that understanding of a gradual "transition," but supplement it by positing a process of ongoing societal evolution resulting in a reconstruction of the modern political economy along both capitalist and socialist lines. This theoretical updating of Social Democracy centers on a new interpretation of the corporation.

Marx first suggested that the corporation, the central institution of the modern American economy since the early twentieth century, was a form of enterprise transitional from capitalism to socialism. More recently, Martin Sklar has developed a theory of the mix of capitalism and socialism, centering not, as with most versions of Social Democracy, on a mix of the public sector (socialism) and private sector (capitalism), but on a mix of capitalism and socialism in both sectors, including the business corporation itself. The corporation, Sklar argues, partially dissolved or socialized capitalist characteristics in several ways. It partially socialized ownership by dispersing property to a larger "public" through stock ownership, eventually mediated on a growing scale by pension plans and other institutional owners with social goals. In separating ownership from control, it created a partially independent managerial class filled with functionaries trained in universities according to the latest scientific, technical, and social scientific knowledge. 
The oligopolistic or socialized market power of corporations allowed managers to plan prices not only at levels needed to cover operating costs associated with replacing old and funding new investment, but also above profit, rent, and interest costs. The significant divergence between price and cost, together with rising productivity, allowed managers to allocate corporate spending to social purposes, for example, to higher wages, shorter hours, and benefits whether negotiated or not by unions, scientific research and development, employee safety, health, training, and recreation, to workplace redesign, philanthropy and charity, and to taxes to fund public goods, such as public utilities and education. These and other socially-disposed allocations of resources, came to be folded into the price system and passed along to producers and consumers in the market. Meanwhile, the new market power enjoyed by large business corporations allowed its managers to plan investment, product development, marketing, and other functions, in such a way as to adjust supply and demand over the long term. ${ }^{3}$

Insofar as corporations in many industries became significantly "clothed with the public interest" they invited government intervention in ways that proprietary firms within the old competitive economy did not, thus laying the basis for many of the reforms associated with Social Democracy. Thus, the new theory is more inclusive of facts than the more well-known theory inherited from early-twentieth-century socialism. It strongly suggests that even without government intervention the corporation, in Sklar's words, "brought with it an ongoing enlargement of the sphere of associative human self-determination, in correlation with an ongoing enlargement of the degree of socialization of the market society." The upshot is a reinterpretation of what has been called the "socialization" process. Rather than a mere generating of conditions with socialist potential to be realized by either revolutionary or gradualist "socialist" politics powered by the working-class, Sklar's theory posits as a working hypothesis the possibility that socialism is an actually existing and evolving set of social relations, driven by the actions of workers, capitalists, farmers, corporate managers, professionals, and social reformers, as well as political socialists. The theory differs from classical Social Democracy in yet another important way: jettisoning the teleology of a socialist conclusion to what earlier 
socialists called "the transition," Sklar writes instead of a continuing "co-development of capitalism and socialism" without preordained end. ${ }^{4}$

The essays in this issue speak to some of the historical questions and issues involved in rethinking the tie of socialism to capitalism, whether in relation to events like World War I, the issues of revolution versus gradualism and utopian versus realistic politics, or the philosophy of pragmatism and its critics.

The first essay in this issue is a further elaboration by Sklar of his work on capitalism and socialism in the U.S., and part of a larger work in progress. In "Thoughts on Capitalism and Socialism: Utopian and Realistic," Sklar invites students of the Gilded Age and Progressive Era to rethink their understanding of the relationship of capitalism and socialism and of the period more generally. Sklar asks us to treat socialism the way we treat capitalism, that is, not simply in terms of forms of thought, parties, or movements, but as basic features of socioeconomic relations, and not just in the public sector but in the private sector institutions of the market and business. As an aid to assimilating this thought process Sklar proposes to think about the economy in terms of capitalist and socialist investment components (CIC and SIC). Viewed in these terms Sklar contends that the SIC has grown continuously in the twentieth century in interrelation with the CIC. Instead of twentieth-century America being conservative or exceptional, as many historians claim or assume, Sklar argues that it has been moving in a "leftward" direction. To help the reader better grasp what he calls "the mix," Sklar presents a historical inventory of public laws, regulatory commissions, public enterprises, and social movements and organizations, which embodied it during the Progressive Era. Sklar concludes by ramifying the binaries of utopian and realistic with two others: left and right, and pro-socialist and pro-capitalist. Complicating socialism this way creates the possibility of a typology of socialisms, for example, right-wing, utopian, pro-socialists (think DeLeon and Lenin), left-wing, realistic, pro-socialists (Berger, Gompers, and Walling) and so on. This new conceptual framework - replacing the old "conceptual grid" holds the prospect of clarifying the questions we ask in our research and generating new working hypotheses for the study of socialism and capitalism in modern U.S. history. 
The point of departure of John P. Enyeart's "Revolution or Evolution: The Socialist Party, Western Workers, and Law in the Progressive Era," is a criticism of the tendency among historians of Progressive Era socialism and left-wing movements to designate one type of socialism - the revolutionary brand relying on the "class struggle" - as the one "true" or "real" type of socialism or left. These historians look to Eugene Debs and William Haywood of the Industrial Workers of the World (IWW) as their touchstone; and they tend to relegate the gradualists, led by Morris Hillquit, to the status of opportunists and conservatives. Enyeart challenges this characterization by focusing attention on the core group of the IWW, the Western Federation of Miners (WFM), along with Western workers generally.

Enyeart shows that by 1908 the WFM had left the IWW and thoroughly rejected its doctrine of perpetual class struggle embodied in the practice of refusing to sign collective bargaining contracts. The union joined the American Federation of Labor and adopted Hillquit's policies of "boring from within" and supporting pro-labor reforms in electoral politics. Indeed, it appears that by the 1909-12 period the center of gravity of the entire party had shifted toward the evolutionist (gradualist) policies of collective bargaining and electoral politics. Enyeart cites the example of the Butte, Montana Socialist Party, which by 1911 rejected its earlier "impossibilism" and created a successful political movement aimed at immediate improvements in workers' lives in their neighborhoods and workplaces. The party's most enduring victory was a statewide workman's compensation act, which became a model for other states - once it had been accepted by the courts. Enyeart concludes that, while historians have credited radical farmers, "maternalist" women, Progressive intellectuals, and major party politicians as architects of modern social democracy, they depreciate the contributions of the gradualist wings of the labor movement and the Socialist Party. This important essay helps restore the balance by shifting our attention away from left "failure" and reinserting the Socialist Party and pro-socialist unions into Progressive Era history.

My essay, "The Odyssey of William English Walling: Revisionism, Social Democracy, and Pragmatic Evolutionism," carries forward in time Enyeart's discussion of socialist gradualism. Walling was a leading non-party socialist intellectual, who played a key role in founding the National Women's Trade Union League and the National Association for the Advancement of Colored People. He joined the 
Socialist Party in 1910 and became a part of the party's revolutionary wing. From 1912 to 1914 , Walling wrote three closely related books rethinking socialist theory, which have become his main attraction to historians of socialist thought. The first book launched a critique of state socialism; the second attempted a reinterpretation of Marxian socialism using the pragmatist philosophy and morality of John Dewey; and the third offered up a complicated and iconoclastic three-stage theory of a transition to socialism. With the advent of World War I and the Bolshevik Revolution, however, Walling left the party, supported the war effort, and reoriented his thinking and political loyalties to progressive democracy and the AFL.

Scholars have treated that turning point in Walling's intellectual career as something of a betrayal of earlier commitments. Accordingly, his work in the 1920s and 1930s has been treated almost as an afterthought. In this essay I propose a reinterpretation of Walling by emphasizing his creative adaptation to new circumstances based on his Deweyan approach of "pragmatic evolutionism." I make two major points. First, Walling's support of the war resulted from a carefully considered rejection of the Socialist analysis that wars were caused by capitalism - and by extension, imperialism. To the contrary, Walling argued that nationalism caused war and that the internationalism of overseas investment was an important precondition for an alternative to war. Second, in his 1926 book, American Labor and American Democracy, Walling offered a reworking, rather than an abandoning, of his earlier socialist beliefs. American society, said Walling was not capitalist; it was a mix of nationalism, democracy, and capitalism, and within that mix capitalism was in decline. He now posited the AFL as the leading force in an emerging progressive, pluralist democracy that would realize many of the ideals he had written about while in the party. I contend that in historical perspective Walling's intellectual reorientation of the 1920 s represented an important contribution to socialist thought - a creative, principled, and pragmatic American version of Social Democracy.

Like Walling, whom he influenced, John Dewey, America's leading pragmatist thinker - and arguably its leading philosopher during the first half of the twentieth century, was a professed socialist intellectual. Also, like Walling, Dewey outspokenly supported America's entry into World War I. That support became a major issue in intellectual history, when Randolph Bourne, in a biting attack, 
repudiated Deweyan pragmatism in light of its apparent illicit compromise with power. The Bourne position was subsequently taken up by the 1920s Young Intellectuals, most of whom, had become disillusioned with the war and its results. By the post-WWII period, that stance had become the norm for left intellectuals from C. Wright Mills and Christopher Lasch to Casey Blake and Robert Westbrook.

In "War and the Intellectuals: Bourne, Dewey, and the Fate of Pragmatism," James Livingston revisits this critical episode in American intellectual history. Livingston begins by questioning his own intellectual affiliation with Lewis Mumford and the Young Intellectuals and his consequent identification of democracy with its nineteenthcentury proprietary variant. He then traces how he came to understand twentieth-century feminism as a "reenactment" of "the deliberate break from epistemology which pragmatism inaugurated," in the sense that it questioned and repudiated the self-contained, transcendental subject. Feminism (and pragmatism) viewed the old individuality as in the process of being assimilated into a new "social self" emerging out of the socialization of all spheres of modern life, including the market, business, and not least, the family. Eventually, Livingston came to understand pragmatism and feminism as modes of thought that "navigated," or made sense of, the transition from proprietary to corporate capitalism and the resulting new socian formation that amalgamated capitalism and socialism.

Turning to the Bourne-Dewey debate, Livingston takes up Bourne's criticisms of Dewey one by one and offers rejoinders, in particular to Bourne's argument that war and the "American promise" were incompatible. Livingston responds that the major alternatives to U.S. entry into the war were either reactionary or undesirable from the point of view of democratic promise. More specifically, Dewey maintained that entry into the war was a way of coming to terms with and furthering an already existing American involvement in the rest of the world by importing into the country the "social question." By throwing "into relief the public aspect of every social enterprise," the war held out the prospect for bringing the implications of the progressive socialization of industry to the forefront of American life, not least in the form of industrial democracy for workers. At the same time, American entry advanced the democratic promise for the belligerent nations. In America's own separation of "language, cultural traditions, all that is called race, from the state - that is, from problems 
of political organization and power," Dewey saw, in large part, the solution to the virulent nationalism that was a source of the war.

Livingston's seminal essay opens up the prospect that historians and intellectuals will revisit the Dewey-Bourne debate and weigh more carefully the merits of Dewey's arguments, not only for their implications for our understanding of World War I and war in general, but for the recovery of the pragmatic outlook. ${ }^{5}$

${ }^{5}$ On the recent revival of pragmatism among American scholars see the essays in John Pettegrew, A Pragmatist's Progress? Richard Rorty and American Intellectual History (New York, 2001); Frank Lentricchia, "The Return of William James," in Ariel and the Police: Michel Foucault, William James, Wallace Stevens (Madison, WI, 1987): 101-33; and Richard J. Bernstein, "Pragmatism, Pluralism, and the Healing of Wounds," in Pragmatism: A Reader, ed., Louis Menand (New York, 1997): 382-401. 